IRA-International Journal of Technology \& Engineering

ISSN 2455-4480; Vol.08, Issue 01 (July 2017)

Pg. no. 1-4

Institute of Research Advances

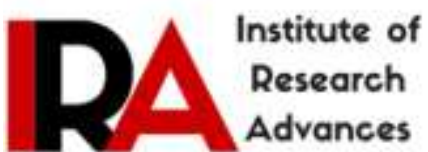

https://research-advances.org/index.php/IRAJTE

\title{
Vermi-Digestion of Municipal Solid Waste by Red Wigglers to Organic Fertilizer
}

\author{
Smita Dhoke $^{1}$, Alka Srivastava ${ }^{2}$, Dr. Parag Dalal ${ }^{3}$, Dr. J. K. Srivastava ${ }^{4}$ \\ ${ }^{1,2}$ Research Scholar, Department of Chemical Engineering, Ujjain Engineering College, Ujjain, India. \\ ${ }^{3}$ Assistant Professor, Chemical Engineering Department, Ujjain Engineering College, Ujjain, India. \\ ${ }^{4}$ Professor and Head, Chemical Engineering Department, Ujjain Engineering College, Ujjain, India.
}

Type of Review: Peer Reviewed.

DOI: http://dx.doi.org/10.21013/jte.v8.n1.p1

\section{How to cite this paper:}

Dhoke, S., Srivastava, A., Dalal, P., Srivastava, JK. (2017). Vermi-Digestion of Municipal Solid Waste by Red Wigglers to Organic Fertilizer. IRA International Journal of Technology \& Engineering (ISSN 24554480), 8(1), 1-4. doi:http://dx.doi.org/10.21013/jte.v8.n1.p1

(C) Institute of Research Advances.

\section{(cc) BY-NC}

This work is licensed under a Creative Commons Attribution-Non Commercial 4.0 International License subject to proper citation to the publication source of the work.

Disclaimer: The scholarly papers as reviewed and published by the Institute of Research Advances (IRA) are the views and opinions of their respective authors and are not the views or opinions of the IRA. The IRA disclaims of any harm or loss caused due to the published content to any party.

Institute of Research Advances is an institutional publisher member of Publishers Inter Linking Association Inc. (PILA-CrossRef), USA. The institute is an institutional signatory to the Budapest Open Access Initiative, Hungary advocating the open access of scientific and scholarly knowledge. The Institute is a registered content provider under Open Access Initiative Protocol for Metadata Harvesting (OAI-PMH).

The journal is indexed \& included in WorldCat Discovery Service (USA), CrossRef Metadata Search (USA), WorldCat (USA), OCLC (USA), Open J-Gate (India), EZB (Germany) Scilit (Switzerland), Airiti (China), Bielefeld Academic Search Engine (BASE) of Bielefeld University, Germany, PKP Index of Simon Fraser University, Canada. 


\begin{abstract}
Ujjain is known as one of the most significant cities of the India as Singhastha 2016 just passed by. Singhastha is an event where Billions of devotees come to take a dip in holy river Shipra for whole One month. In Ujjain average total solid waste generation now is about 226 tons per day in the city area only. A huge amount of money is spent by the Local government on the solid waste management transportation to trenching grounds. The trenching grounds are situated at $20 \mathrm{Kms}$ away from the city in different directions. Solid Waste Management also produces various problems which create many issues with wastage of money therefore; a big need for the ecofriendly disposal technique is been posted. In this paper we are proposing a technique known as vermicomposting which is a good solution to treatment of organic solid wastes. In this technique we have found the degradation of organic municipal solid waste by earthworms. In the research work the temperature is been maintained at $25-35^{\circ} \mathrm{C}$, moisture content maintained about at 45 55\% and $\mathrm{pH}$ between 7.0-7.3. About 100 grams earthworms \{Eisenia Fetida\} per kilogram of municipal solid waste were taken. The final result shows that the organic municipal solid wasted are been converted to manure in a time period of 35 - 36 days through vermicomposting technique and about $63 \%$ volume of municipal solid waste is reduced for transportation.
\end{abstract}

Key words - Municipal solid waste, earthworms, vermicomposting, environmental benefits, Eisenia Fetida, eco- friendly disposal technique

Introduction - Municipal solid waste management is becoming a critical issue now because of rapid increase in population and changes through human activities. 63\% of municipal solid waste is the biodegradable or organic waste. It is a non hazardous substance generated by the daily activities of human life. The major sources of municipal solid waste are households, commercials, institutional, industrials, markets etc. Vermicomposting is an eco-friendly and low cost process with the use of earth worms for the degradation of organic waste to manure. In this research we tried to find out a suitable option of municipal solid waste management using by earthworms to reduce $63 \%$ of municipal solid waste volume of transportation.

Current status of Municipal Solid Waste Management in Ujjain city - Solid waste largely increases is due to the population explosion in Ujjain city from the last decade; therefore increase to waste rises from $340 \mathrm{Kg}$ per day (Dalal, 2005) to 226 tons per day (Dalal,2012). Urban area of Ujjain city is about 93 sqs. Kms. and the Population is $5,15,215$ (2011 census). The urban area is been sub-divided into six zones and 54 wards. Waste generation rate per capita is about 0.37-0.45 Kg per day (Sharma, Dalal et al., 2017). The management of municipal solid waste is done by the municipal corporation of Ujjain now a day's two private consultancies joined the management of solid waste of the city.

Fig - 1 Percentage of waste generation by different type of sources

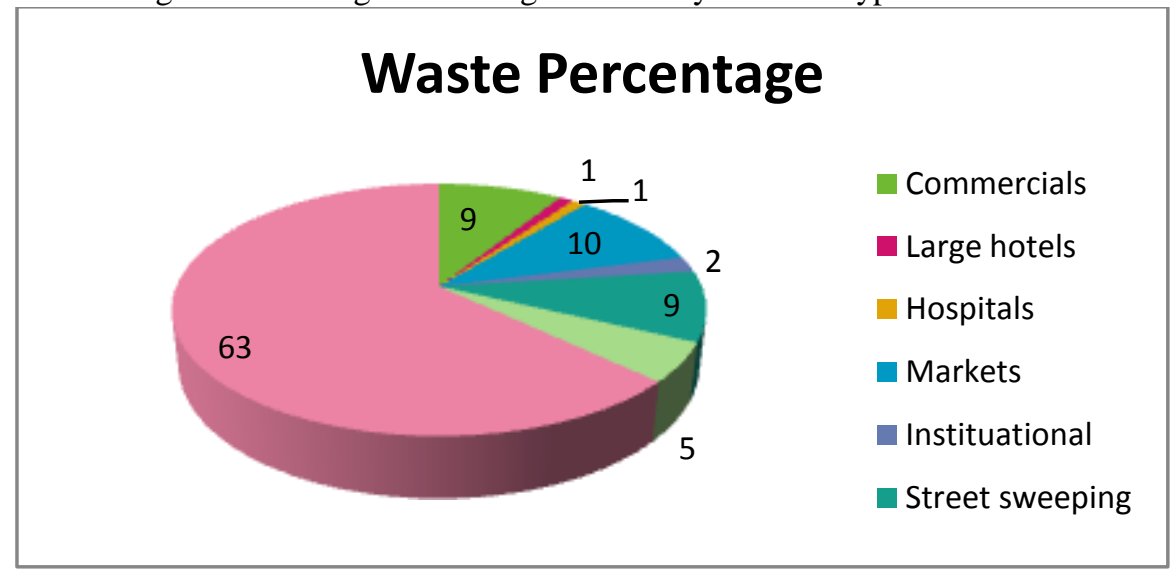

Collection of solid waste management has been done by a daily Door to Door technique from households and commercial areas by mini-trippers, hand-craft etc., these equipment's are equally distributed ward wise in city according to the mass density ratio of the solid waste generated. The transportation process is done using heavy vehicles for bulk transportation. Two modular transfer stations are situated at MR-5 Maksi road bypass and Gaughat consisting of compactors, hook loaders etc., which contracts the solid waste for future transportation. 76 mini-tippers 
with the size of 3 cubic meters and 15 compactors with the capacity of $1300 \mathrm{~kg}$ each has been used by Ujjain Municipal Corporation for Door to Door collection and its transportation.

Table 1 shows that types of vehicle in the Ujjain city (Sharma, Dalal et al., 2017)

\begin{tabular}{|l|l|l|l|}
\hline S. No & Types of Vehicles & No. of Vehicles & No. of trips per day \\
\hline 1 & Mini Tippers & 76 & 3 \\
\hline 2 & Hook Loader & 05 & 1 \\
\hline 3 & Compactors & 15 & 2 \\
\hline 4 & Dumper Placer. & 02 & 3 \\
\hline
\end{tabular}

Collected municipal solid waste is being transported to Gondiya trenching ground situated about $20 \mathrm{kms}$ north west from the Ujjain city. Municipal Solid Waste is being processed in various steps. First the waste is been sent to segregation process where organic waste is segregated from the remaining plastic, papers etc. This segregated organic waste goes through the window composting. This will turn into final output of organic manure having size of 2-4 $\mathrm{mm}$ and can be sold in the market. The unprocessed waste is being dumped in a four meters deep pit. Which is 140 meters long and 120 meters wide. The cost this type of management of MSW is very high and can be reduced by using the eco-friendly technology for municipal solid waste proposed by us.

Experimental Methods of Municipal Solid Waste Treatment - The organic waste needed for data is collected on a daily basis from residential area. The vermicomposting process is done in two reactors and the third reactor is taken as control. Size of each reactor is $50 \mathrm{~cm} \times 30 \mathrm{~cm} \times 30 \mathrm{cms}$ so the total capacity is 0.045 cubic meters (Dalal, 2012). These reactors are filled by the MSW and varied weight of earth worms are loaded into them. In the control reactor no earth worms are been added and the earth worms feded in organic materials excrete out granular mounds of worm cast and breakdown complex substances into non complex water soluble substances. Earth worms are responsible for all these process (Hidalgo et al., 2006). The enzymes are also helpful in this reaction against present symbiotic microbes. The Vermicast contain all essential nutrients including micro-nutrients which can be used as bio-fertilizers in agriculture, gardening etc., (Pramanik et al., 2007).

The Setup - Three vermireactors are designed each of these having dimensions $50 \mathrm{~cm} \times 30 \mathrm{~cm} \times 30 \mathrm{cms}$ having capacity of 0.045 cubic meters. A small opening for aeration and drainage system of water in side is given at bottom. The water is sprinkled from the top to maintain the moisture to $50 \%$ and by water the $\mathrm{pH}$ remains near to 7.3 . It is the most familiar conditions for the vermicomposting process as organic material of $10 \mathrm{Kgs}$ was filled in the each reactor with earth worms loading as 0.0 grams for first reactor $R_{1}, 500$ grams in second reactor $R_{2}$ and 1000 grams in third reactor $\mathrm{R}_{3}$ then performance of the reactor is been observed for about five weeks (35-36 days).

\section{Results and Discussions -}

Table no.-2 - Reactors and Manure Production -

\begin{tabular}{|c|c|c|c|c|c|c|c|}
\hline \multirow{2}{*}{ Days } & $\mathrm{R}_{1} \mathrm{MSW}$ & $\mathrm{R}_{2} \mathrm{MSW}$ & \multirow{2}{*}{ Manure } & \multirow{2}{*}{$\pm \mathrm{SD}$} & $\mathrm{R}_{3} \mathrm{MSW}$ & \multirow{2}{*}{ Manure } & \multirow{2}{*}{$\pm \mathrm{SD}$} \\
\hline & (Liters) & (Liters) & & & (Liters) & & \\
\hline 0 & 20.00 & 20.00 & 0.00 & 0.00 & 25.00 & 0.00 & 0.00 \\
\hline 2 & 17.90 & 13.70 & 0.34 & 0.02 & 19.60 & 1.90 & 0.12 \\
\hline 4 & 16.40 & 12.00 & 1.54 & 0.10 & 18.95 & 2.55 & 0.16 \\
\hline 6 & 15.00 & 9.80 & 1.95 & 0.12 & 17.10 & 2.62 & 0.17 \\
\hline 8 & 12.70 & 9.20 & 1.95 & 0.12 & 14.20 & 2.62 & 0.17 \\
\hline 10 & 10.60 & 8.10 & 1.95 & 0.12 & 14.00 & 2.62 & 0.17 \\
\hline 12 & 10.60 & 7.30 & 2.00 & 0.12 & 14.00 & 2.62 & 0.17 \\
\hline 14 & 10.60 & 7.30 & 2.12 & 0.13 & 14.00 & 2.62 & 0.17 \\
\hline 16 & 10.60 & 6.90 & 2.40 & 0.15 & 14.00 & 2.62 & 0.17 \\
\hline 18 & 10.60 & 6.90 & 2.40 & 0.15 & 10.00 & 3.80 & 0.24 \\
\hline 20 & 10.60 & 6.90 & 2.40 & 0.15 & 10.00 & 3.80 & 0.24 \\
\hline 22 & 10.60 & 5.60 & 3.90 & 0.24 & 8.40 & 4.17 & 0.26 \\
\hline 24 & 10.60 & 5.60 & 3.90 & 0.24 & 8.40 & 4.17 & 0.26 \\
\hline 26 & 10.60 & 5.60 & 3.90 & 0.24 & 8.00 & 6.70 & 0.42 \\
\hline 28 & 10.60 & 5.60 & 3.90 & 0.24 & 4.60 & 7.15 & 0.45 \\
\hline
\end{tabular}




\begin{tabular}{|l|l|l|l|l|l|l|l|}
30 & 10.60 & 3.40 & 4.50 & 0.28 & 3.30 & 8.00 & 0.50 \\
\hline 32 & 10.60 & 2.40 & 6.95 & 0.43 & 2.70 & 8.03 & 0.51 \\
\hline 34 & 10.60 & 0.80 & 7.35 & 0.46 & 0.80 & 8.07 & 0.51 \\
\hline 36 & 10.60 & 0.00 & 8.12 & 0.50 & 0.00 & 8.19 & 0.52 \\
\hline
\end{tabular}

Vermicomposting result depicts that the bioconversion of waste stream is been converted into two useful products, earthworm's biomass and vermicompost. The viability of using earthworms is more as the treatment technique also produces organic fertilizers. In this research it is indicated that during vermicomposting the $\mathrm{pH}$ declines (from 7.0 to 7.3) with the advancement of vermicomposting time period (from 0 to 36 days). On the first day we see no changes of color in reactor $R_{1}$ but reactor $R_{2}$ and $R_{3}$ shows very small changes. On second day we observe small changes in $\mathrm{R}_{1}$ but in $\mathrm{R}_{2}$ the waste start converting into manure and in $\mathrm{R}_{3}$ the waste start converting into manure. The earthworms are traveling through the downward direction with the change of color in the same direction. The green waste started to convert into black/blackish brown in $R_{2}$ and $R_{3}$ (from 4-10 days) and $R_{1}$ reactor remains greenish. During all five weeks we maintain the temperature $\left(25-35^{\circ} \mathrm{C}\right)$ for earthworms. In all three reactors on the third week we observe that 2.42 liters of manure is present in reactor $R_{2}$ and 2.60 liters of manure is present in reactor $R_{3}$.

After five weeks volume reduction in first reactor $R_{1}$ is about $49 \%$ were there is no vermicomposting also the color of the source does not change much and remains greenish. In second reactor $R_{2}$ were we put 500 grams of Eisenia Fetida the color starts changing from fourth day and the volume of manure after $36^{\text {th }}$ day is 8.12 liters which is about $60 \%$ of the weight. In third reactor $\mathrm{R}_{3}$ where we have put $1 \mathrm{Kg}$ Eisenia Fetida, which results as 0.0 liters of municipal solid waste and the manure is 8.19 liters which is about $67.5 \%$ of the weight.

Conclusion - Material for vermicomposting are easily available so it can be practiced at commercial areas as well as individual homes for very small cost differences. The practice of vermicomposting has many benefits: firstly it reduces the cost of the overall solid waste management system of the government and secondly introduces on site recycling of the organic waste. Thirdly it is homemade fertilizer which is ready for our garden. We can construct a simple reactor for vermicomposting in each house for biodegradable waste decomposing in a big flower pot.

Future scope for vermicomposting - For the waste of vegetables vermicomposting is to be done with new specific spices of earthworms Perionyx Ceylanensis Perionyxexcavtus, Perionyxhawayana, Lumbricusrubellus, D.veneta, LampitoMauritii with different animal dung \& agro waste. The household small scales units of anaerobic bio gas digesters \& Vermicomposting of Biogas Sludge (organic slurry) can be developed to reduce transportation cost \& G.H.G. Emission from municipal solid wastes. Institutional units need to be installed for both Bio Gas generation \& Vermicomposting and also the amendment in the law need to be done for following vermicomposting.

\section{References}

[1] Dalal Parag (2005) Sustainable development of Holy city Ujjain, India by Solid Waste Management. Journal of Pollution Control Vol 21(2) 2005 Pg. 127-132

[2] Dalal Parag (2006) Sustainable development of Ujjain by Solid Waste Management. Our Earth Vol 3 (2) pg 5-11.

[3] Dalal Parag (2011). Liquid Biomedical waste management strategy. Environmental Conservation Journal Vol 12(1\&2). Pg. $87-93$

[4] Dalal Parag (2012) Municipal solid waste Management by Vermicomposting. International Journal of Science and Nature. Vol 3(4) pg 883-885.

[5] Aditya Sharma, Dr. Alka Srivastava, Dr. Parag Dalal and Dr. JK Srivastava (2017). Proposal of on - Site composting of MSW in Ujjain city. International journal of chemical studies, 5(3): 89-92.

[6] Dalal Parag (2017) Systematic Approach to Integrated Solid Waste Management System by Green Cleaning of All Municipal Area of City Ujjain, India International Journal of Development Research Vol. 07(05), 2017 pg. 12752-12753

[7] Garg V.K., Kaushik P., and Dilbaghi N., (2006). Vermi conversion of wastewater from textile mill mixed with anaerobically digested biogas plant slurry employing Eisenia foetida. Ecotoxicology and Environmental Safety, 65(3):412-419.

[8] Gupta R., Mutiyar P.K, Rawat N.K., Saini M.S., and Garg V.K. (2007). Development of a water hyacinth based vermireactor using an epigeic earthworm Eisenia foetida. Bioresource Technology, 98(13):2605-10.

[9] Hidalgo P.R., Matta F.B., and Harkess R.L. (2006). Physical and chemical properties of substrates containing earthworm castings and effects on marigold growth. Hortscience, 41(6):1474-1476.

[10] Pramanik P., Ghosh G.K., Ghosal P.K., and Banik P. (2007). Changes in organic and enzyme activities in vermicompost of biodegradable organic wastes under liming and microbial inoculants. Bioresource technology, 98(13):2485-94. 